\title{
China's Education System: Loved and Hated
}

\author{
Mette Halskov Hansen \\ University of Oslo
}

\begin{abstract}
China has the largest education system in the world, and a population who values formal education highly and is ready to invest heavily in children's schooling. As much research has shown, this reverence for education is only partly due to rational considerations of offspring's' work opportunities. It also has its roots in a long historical trajectory of highly esteemed Confucian education and civil service exams. Since the time of the PRC, the education system has undergone a number of radical structural reforms and adaptations of content of education. Nevertheless, methods of teaching and means of socialization have proven remarkably persistent, causing intense debates about the pros and cons of the Chinese education system. The article first provides a brief overview of the structure of the education system as it has developed during the PRC, with an emphasis on the 21. century. This is followed by three sections focusing on "Knowledge and exams", "Socialization and discipline" and "Alternative paths" that places the Chinese current education system in the broader global web of educational institutions and ideologies. The article analyses and discusses why and with which consequence the Chinese population and its government have cultivated a love-hate relationship with their own education system, and it concludes with some suggestions for future research.
\end{abstract}

Keywords

China's education system, Chinese schools, vocational education, China's exam system, Confucian education, civic education, Chinese students abroad, educational hierarchies

\section{Introduction}

By the end of China's last dynasty Qing (1644-1911) every second or third boy, and only a tiny minority of girls, would get basic training in reading and writing classical texts in one of the widespread Confucian private schools (Thøgersen 2002, 22; Rawski 1979, 23). A hundred years and many educational reforms later China stood out as the country hosting the world's largest state education system. Government policies and state investments had essentially guaranteed nine years of universal free education by 2010 , and many parents were willing and able to invest privately in the further education of sons as well as daughters. However, the Chinese people's educational desire (Kipnis 2011) had long been accompanied by severe criticism against the form and content of schooling. High officials started to send their own children to American ivy league universities, and a growing number of affluent middle class parents paid for children's education in less prestigeous, but still "western", educational institutions. At the same time, social status, gender and ethnicity continued to create deep discrepancies between the actual quality of children's education and their career options. The government itself ponder on the 
basic dilemma of how to promote innovation and creativity in an exam driven school system designed also to socialize youth in the spirit of political compliance.

The Chinese education system has been subjected to a great amount of research, much of it quantitative studies aimed at developing policy recommendations. However, The aim of this article is to show how especially anthropological and historical research of Chinese education may offer deeper insights not only into the practices of Chinese education but of broader theoretical issues concerning Chinese policy and society. The Chinese school is a sort of miniature society where people from all ranges of society study more or less the same text books, but nevertheless interact and interpret their tasks as students, parents or teachers in different ways. Especially observations and participant observations in and outside schools (and not merely during classes) combined with indepth interviews (which are in themselves insufficient to understand daily practicies) are useful methodologies for providing insights reaching beyond the specific pedagogical and epistomological aspects of education. In the following, the academic field of "Chinese education" is therefore opened up to include, and even focus on, research that approaches the Chinese education system as a case for understanding larger societal and political dynamics.

The Chinese people's well-known reverence for education has roots in the historical trajectory of highly esteemed Confucian education and civil service exams (Elman and Woodside 1994; Lee 2000). Confucian ideals of lifelong learning and dedicated study have undoubtedly helped to shape popular notions of the elevated status of education. However, culturalist explanations are vague and not nearly sufficient to account for how Chinese state education has evolved and been received by the population, what kind of knowledge it has sought to promote, and how it became the subject of intense debates at all levels of society and in the political system. While formal education has enjoyed high prestige throughout China's history and showed remarkable signs of continuity, changing economic realities and political priorities have continously influenced its form and content as well as people's practices and perceptions of it.

The article starts with an outline of the development of Chinese modern education with an emphasis on the period of the People's Republic of China (PRC) since 1949. It continues to discuss in some detail three key issues, each of which help to highlight the connection between the "inner life" of the Chinese education system and its broader context of society and politics in the global education market. The article ends with some reflexions on the way ahead for the Chinese education system and the research of it.

\section{Developing Modern State Education}

To "have culture" (wenhua) in China means to be educated or, more precisely, to have gained access to China's long cultural history through the study of written texts (Thøgersen 2002, 3). In the Confucian private sishu schools that existed well into the $20^{\text {th }}$ century, fortunate boys would spend a few years of their lives reciting a fixed set of Confucian classics and primers and practicing to write characters. Those who performed best, and whose family could afford to keep them longer in school, would 
continue to ever higher levels of the civil service examinations in the distant hope of becoming part of the imperial bureaucracy.

This hierachical structure of civil examinations was based on uniform Confucian ideology and dates back to the Sui dynasty (A.D. 581-618). After having found its final form during the Ming dynasty (1368-1644) it remained basically unchanged for 500 years until the period of intense modernization started with the fall of the last dynasty and the beginning of the Chinese Republic (1911-1949) (Pepper 1996, 47). Western powers had disrupted Chinese emperial political structures and society since the Opium Wars especially (1840-42 and 1856-60), and the Chinese revolutionaries now argued for the need of a thorough transformation of education in order to adapt to the demands of a technologically much more developed West. The traditional emperial examination was abolished in 1905 and school school subjects that were completely novel to the Chinese population, such as modern vernacular, citizentry, geography, math and physical education, were introduced. ${ }^{i}$ So was the idea, borrowed from Germany and US, that modern education should offer not only an academic but also a vocational (zhiye) track that would transmit useful technological knowledge and skills to the wider population. ${ }^{\text {ii }}$ The modern Chinese education system as we know it today had started to take form. ${ }^{\text {iii }}$

Between 1937 and 1948 China went through a turbulent period of civil war and Japanese occupation. This also caused a set-back for the republican ambitions of universal modern education and in response traditional private Confucian schools started again to mushroom. When finally the Communist Party (CCP), with Mao Zedong as its paramount leader, came to power in 1949 the new state faced the enormous task of developing a form of education that was commensurate with Party ideology and fit to develop the new People's Republic of China (PRC). As the ruling power ever since the Communist Party has taken the education system on a very winding path, as we shall se in the following.

\section{Education During the Mao Years}

From the establishment of the People's Republic of China (PRC) and until the Cultural Revolution started in 1996, the Party and government's ambition was to finally achieve the true basic mass education that the Guomindang leadership of the Republic had never managed to implement. Elementary school was supposed to be for everyone - boys and girls ${ }^{\text {iv }}$ - secondary schools for a selected cohort, and higher education for the few. In addition a number of large scale illiteracy campaigns for adults were initiated.

The CCP had already some experience setting up their own schools in the areas they had controlled during the full-scale civil war from 1946, and they had come to regard education as a very important weapon in the struggle for national survival (Thøgersen $2002,127)$. After their victory in 1949, they looked to their ally, the Sovjet Union, rather than to the US or Germany to find a model for a new form of mass education. The demands for correct Communist moral and political teaching was emphasized but in general, as China scholar Stig Thøgersen notes, the tone during the first years of the PRC was pragmatic. China needed cadres, technicians, and skilled workers at all 
levels to get the economy running after years of war and unrest, so the training of such personell and teachers was given a very high priority (Thøgersen 2002, 140).

Education also needed to be rebuild and developed as a tool to secure the borders of the PRC under CCP leadership. During the Long March (1934-35) political leaders had already promised numerous ethnic minority peoples living in the vast western border regions that with the CCP in power they would recieve recognition as "ethnic minorities" (shaoshu minzu) and enjoy a high degree of political automomy in specially designed regions. New cadre training for ethnic minorities was set up and schools teaching minority languages in addition to Chinese were initiated in areas inhabited by, for instance, Tibetans, Uighur, Tai, and Miao. ${ }^{\mathrm{v}}$

Larger transformations of a state's education system tend to emulate changes in the authorities' more general political preferences. After the launching of the anti-rightist campaign in 1957 and the break with the Sovet Union, China entered a period of radicalization that lasted until Mao's death in 1976. The famine, atrocities, and endless personal tragedies that these policies caused are well documented (e.g. (Dikotter 2010; Dikötter 2016). Also with regard to education many things went very wrong in this period, while a few others were probably more positive than the dominant Chinese and Western narratives about this period tend to claim. Secondary education was practically put at a halt during the high tide (1966-69) of the Cultural Revolution (1966-76). Red Guards were first encouraged by Mao to rebel against their teachers and school authorities, and then, in 1969 when things seemed to be spinning out of hand, millions of urban youth were sent to the countryside to live and work as peasants. Class background, rather than school performance, tended to decide an individual's educational options, and throughout this period there was an intense emphasis on political correctness in schools as in society in general. ${ }^{\mathrm{vi}}$ At the same time, this period undoubtedly saw a spectactular expansion of basic mass education that benefited not least disadvantaged girls and rural areas (Thøgersen 2002, 166-67).

Another remarkable thing about the education system in the 1960s and 70s was the extent to which it developed in almost isolation both from the dominant socialist part of the world led by the Sovjet Union, as well as from the capitalist countries that were slowly starting to increasingly synchronize their systems of education. China had student exchange with developing countries on a small scale only, and the real integration of its education into the global capitalist dominated system came only after Mao's death in 1976 and the start of Deng Xiaoping's celebrated national "reform and opening policy" (gaige kaifang) from 1979.

\section{The Globalization of China's Education}

The vast majority of the Chinese population seemed highly relieved when the radical Gang of Four was taken from power and economic policies took an sharp turn in the 1908s towards supporting trade and individual ownership. And in spite of some scepticism towards the sudden negation of the Maoist experiments with the expansion of rural education, most people seemed to applaud the reintroduction of a centralized college entrance exam (gaokao) in 1977, the return to more strictly academically regulated education, and the restablishment of key point schools for the best students. 
The acclaimed anthropologist, Yunxiang Yan was able to sit succesfully for the newly reinstalled national entrance exam in 1978 after having received very little education during the Cultural Revolution. His personal story up to that landmark day epitomizes the fate of many urban youth during this period:

I was born in Beijing, China. In 1966, like some 200,000 other people nationwide I involuntarily became an impoverished villager when my family was expelled from the city to a remote village due to my father's political opinions. In the same year I was forced to drop out of primary school and to work as a shepherd, farmer, and seasonal manual laborer in rural China until 1978. As a young political outcast living and working in two villages during this 12year period, I had more opportunities than many of my peers to experience the devastating economic hardships (including famine) and the brutal political oppression under radical Maoism.

Regardless, I benefited a great deal from living at the very bottom rungs of society as I learned directly from everyday life what really matters to ordinary people.

(Yunxiang Yan, UCLA webpage

http://www.anthro.ucla.edu/faculty/yunxiang-yan (accessed 30.05.2016)

When finally in 1977 everybody regardless of class, age or gender were again allowed to take the college entrance exam, nearly 5,7 million people signed up. Less than 5 percent of them were admitted to college ${ }^{\text {vii }}$ According to the Ministry of Education, the exam at the time was considerably easier than today. Potential students had lost years of academic training and therefore the standard of exams could not be too high. Moreover, as of yet there were few places in universities and colleges available for the expectant youth. Compare these figures to the 2010s. It has been forty years since the college entrance exam was revived and every summer since there has been intense competition among high school graduates from all over the country to get into the best possible universities and colleges (all called daxue in Chinese). The exam is tough but the number of universities and colleges have expanded enourmously and in 2014 more than 9 million high school graduates sat for the exam and 74 percent of them got into a college. Maybe not into the college of their dreams, but at least some kind of tertiary education became available for them.

Since the 1980s, the authorities have initiated a broad range of reforms in order to incorate China into the global market economy. It is therefore not surprising that it has simultaneously sought to also increasingly adapt the education system to dominant global trends. To summarize, it has consolidated schools locally all over the country by moving the financial and academic responsibility for them upwards in the system. It has merged schools and made larger units, often making it necessary for students to board at schools. It has reinforced the division between vocational and mainstream education tracks, invested more in vocational training while simultaneously supporting the development of academic elite schools at all levels. Not least, it has opened up the possibilities for youth to study abroad.

During this period of globalization the population has continued to express a consistent desire for education that has undoubtedly been strengthened by the one- 
child policy, implemented since 1979. Especially in urban areas parents would put all their hopes for the future on to the one child. ${ }^{\text {viii }}$ Even in rural areas where many would still have two or more children, parents looked for creative ways of navigating a competitive education system. ${ }^{\text {ix }}$ All over the country people have invested privately in tutors for their children, moved to areas where schools were better, used "the back door" to get into schools, counted on boarding schools for providing better academic support than their own family, or saved money to send a child abroad. Chinese parents focus on education in the hope that it will secure a child's, and therefore the family's future, but also, and maybe even more so, because it has become the norm in Chinese contemporary society, it is what is expected of you as a parent.

In this atmosphere of what anthropologist Andrew Kipnis has poignantly defined as educational desire, it is easy to overlook the inherent hierarchies and social gaps that are just as much a product of the modern system of education as is the succesfull universalization of basic schooling. By the 2010s, China had largely (though not completely in the poorest rural areas and urban migrant communitieis $)^{\mathrm{x}}$ succeeded in achieving the nine years of compulsory and free education that was the aim of the Compulsory Education Law of 1986. Furthermore, about $85 \%$ of a cohort of graduates from junior high school would at some point in their lives enroll in a vocational, regular, or adult high school. So far, most studies of educational hierarchies have focused on this well-known rural-urban divide that is still, in effect, very often a devide between poorer and richer areas, schools, and families. However, as anthropologist T. E. Woronov (T. Woronov 2015) has shown, in urban areas it makes a world of a difference, career- as well as and status-wise, whether one tests into a vocational or a regular (academic) high school. "Education" within the state school system means many different things in practice, and in following we shall therefore first take a closer look at how the examination system helps to maintain hierachies of knowledge and serves to consolidate social class.

\section{Knowledge and Exams}

Exams form an integrated part of educational systems all over the world. In China, formalized exams have an especially long historical trajectory. The imperial examinations constituted a pre-modern expression of the ideal of meritocracy. The selection of officials was supposed to be based on impersonal and objectified testing of the individual's ability to memorize and reproduce a fixed set of knowledge and skills. This, arguably, helped lay the ground also for the culture of examination that shapes education in contemporary China.

The practice of root learning and emphasis on memorization has basically survived through all of the educational reforms of the past hundred years. During my fieldwork in a high school in a relatively affluent rural area between 2008 and 2012, I was struck by the similarities with what I had found in much poorer ethnic minority areas in Yunnan nearly 20 years earlier in 1994-95. ${ }^{\text {xi }}$ Sure enough, curricula had changed, teachers were better trained, students were from very different cultural and economic backgrounds, and mobile phones and social media had created new means of communating and gaining access to information for students and teachers alike. Nevertheless, the emphasis on root learning, emulation of role models, requirement for reproduction of predefined truths in class, in home work, and during examinations, 
all of this remained intact and continued to dominate pratices of teaching and learning.

If, again, we then approach education as a case to understand larger societal dynamics it makes sense to argue, as sociologist Børge Bakken (Bakken 2000) has done, that China's practice of examination is much more than an expression of a meritocratic ideal. It is one aspect of a broader form of governing by which students (and other citizens) are taught to emulate what Bakken calls exemplary models. Rather than emphasizing critical approaches to established knowledge, students in China learn to memorize, reproduce, copy and imitate models that could be, for instance, an accomplished teacher, a patriotic piece of art, a well written political statment, or a Communist youth hero like Lei Feng. ${ }^{\text {iii }}$

The form and content of examinations and tests at all levels of education help to consolidate the practice of memorization and root learning within the class room. It is a practice that has been criticized by so many teachers and educators, even by the government itself. Since the 1990s the authorities have introduced reforms for "quality-in-education" xiii (suzhi jiaoyu) with the intention of handling in a better way the inherent dilemma of an education system that should simultaneously strenghten adherence to authority and encourage innovation. However, the examination system and fundamental dilemma - remain, because too much much is at stake politically and socially.

In China where corruption is widespread the examination system, with all its acknowledged flaws, is still perceived as the most objective possible form of selection. As Kipnis writes, exams are often viewed in China as the only method that produces social hierarchies that the public find legitimate (Kipnis 2011, 124). And exams in China do produce social hiearchies. In a groundbreaking study of China's vocational education, Terry Woronov (2015) shows how the exam system purposedly devides youth at an early age into two social groups: Those who succesfully pass the High School Entrance exam after nine years of schooling, and those who dont and therefore, already from a young age, are destined to become working class citizens. Other studies have long pointed to the fact that vocational schools have a low status in the hierachical system of education, and that those approximately 45 per cent who continue into vocational education tend to be considered as failures, lazy, sometimes even stupid and with bad influence on other students. ${ }^{\text {xiv }}$ However, Woronov's analysis goes deeper to demonstrate how vocational schooling in China is partly an excercise in class formation. Students in vocational classes learn to endure boredom, tolerate authority, be flexible workers, and amuse themselves with limited ressources. These skills, Woronow argues, are relevant for the kinds of jobs they are likely to get after graduation, namely low-end urban service sector jobs (T. Woronov 2015, loc 1856). Voc ed graduates will not become part of the new shiny urban middle class, but having graduated from vocational high school (sometimes college) they will also not be part of the traditional urban industrial working class. ${ }^{\mathrm{xv}}$

More research is needed to understand what it means to become part of the vocational education track in urban and rural areas, and what role the education system at large plays for the formation of class and social status in the Chinese "socialist market economy". This also leads to the question, discussed in the following section, of how 
schools actually teach and socialize students in more general to become proper citizens in an authoritarian political system with a partly liberal captalist economy.

\section{Socialization and Discipline}

How are students taught to become citizens and what may the study of education tell us regarding the status of the individual in contemporary China? The analysis of textbooks is undoubtedly one of the most important methodologies for understanding the official concious and explicit views on what kind of knowledge and which values

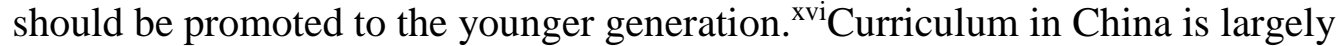
centralized and standardized and in spite of some possibilities of local adaptations and variations, a formal political control system ensures that all textbooks remain in line with official guidelines.

Consequently, in the subjects considered most important for providing moral and political training there is no substantial difference between textbooks in, for instance, an elite school in Shanghai and a rural school in Yunnan. Courses on morality, values and policy perceptions are taught for all students at all levels of the compulsory Chinese education system. Together with language/literature and history they constitute the most important subjects for disseminating the official view on patriotism, the role of the Communist Party, and the rights and responsibilities of the individual in the PRC (M. H. Hansen 2015, 69). Especially the text books in Thought and Values in junior secondary school (grad 6-9) and Thought and Politics for high school (grades 10-12) are, as researcher of Asian education Edward Vickers notes, most intimately associated with official ideological correctness, and they therefore also serve as benchmarks for the broader school curriculum (Vickers 2009a, 55).

Vickers has formulated quite precisely what kind of citizens the Communist authorities hope to achieve through its education system in the era of global capitalism:

[E]ducational policymakers in China would like to be able to foster in Chinese pupils the kind of initiative, boldness and innovative spirit which they see as among the more positive outcomes of many Western education systems, while divorcing these attributes from the liberal-democratic ethos of the societies in which these systems have arisen.

(Vickers 2009a, 65)

This ideal has, as also discussed above, prompted a number of reforms attemting to engage students more in their studies. Especially since the curriculum reform of 2007, new school book texts were supposed to appeal more to students' own interests. Thus, students at the high school level now read a variety of texts ranging from Confucian classics to the diary of Anne Frank and a study of MacDonalds restaurants in China. Unsurprisingly, however, the continous dilemma of the neo-socialist ${ }^{\mathrm{xvii}}$ ideal of combining capitalist economy and leninist authoritarian governance is still directly reflected also in textbooks. 
In my own fieldwork within a Chinese rural high school, for instance, there were endless examples of how text books and teachers had started to put forward more open-ended questions for students to discuss. But they did, at the same time, also make sure that the final "correct answer" was available in case discussions move in the "wrong" direction (M. H. Hansen 2013; M. H. Hansen 2015). Students were taught that while they should reflect on and discuss certain issues they should always accept that a definite final morally and politically correct answer exists. Therefore, history is taught like a series of facts that are hardly open for interpretation, basic Confucian texts of high moral value are memorized and recited, and the correct answer to any given (important) question is practially always directly available within a textbook or teacher's manual.

Studying text books wil reveal a lot about official dicourse and values. Other research methodologies are required to understand what in practice is being taught in schools beyond the text books, and, not least, what students then actually learn about themselves as members of the societal collective and as individuals. In my own study (Hansen 2015) of how and to which extent the rise of the individual ${ }^{\mathrm{xviii}}$ in post-Mao China is reflected within the education system, I found, for instance, that rural boarding high school students tended to express a very high degree of personal feeling of responsibility for any degree of failure or success in school. They were not really happy with school authorities' attempts to use their student council mainly for the purpose of disciplining fellow students, and they were frustrated about the limitied options they saw for real social mobility after high school because of their low grades and disadvantaged positions as rural residents. They would blame themselves for this. They would not criticize parents because they knew that they had less education than themselves and were mostly struggling to keep their children in school believing that it would provide them with a better future. They would fiercely criticize the education system in general for a lot things - for being boring, adding too much pressue, limiting their freedoms - but they did not blame their wn school or the teachers as such for the situation. Most seemed to agree that the education system, including the exams, had a form and content which was necessary in such a populous country still in the process of developing economically.

However much the education system is critized today for not supporting the kind of innovation and creativity that continued economic growth and China's ambitions in the world requires, the prospect of profound change is dire. Firstly, because the neosocialist state needs to ensure loyalty to the one-Party state. Secondly, and no less importantly, because most people continue to trust that the education system serves in their private interest by, at least in principle, providing the main path to upward social mobility, and ensuring that their children are taken care of in a highly regarded and strictly governed state institution during most of their time.

There are important cracks in this system, though, and they are growing. If the prediction that only relatively superficial changes to the exams and the form/content of education system will be implemented under the current political regime, is there maybe a growing risk that the Chinese education system will loose prestige nationally and mainly become attractive for those who cannot afford otherwise? Certainly, a growing number of Chinese middle class parents are now following in the heels of the political and financial elite by supporting their children's study abroad, as discussed in the following. 


\section{Alternative Paths}

In 2015, a historically high number of 523,700 students left China to study abroad, adding to the total number of approximately 4 million students who have studied abroad since 1978 (ICEF Monitor 2016). Why are people choosing this alternative path when the Chinese education system in general enjoys a high status? Vanessa Fong's comprensive and long-term study of Chinese students abroad provides the following answer:

Chinese citizens in my study went abroad hoping to become part of
the developed world by getting citizenship or permanent residency
rights in a developed country, earning enough money from work
abroad to start lucrative businesses in China, and/or earning
developed world college degrees that could help them win
prestigious high-paying jobs in China or a developed country.
(Fong 2011,95)

By 2010, as much as 20 percent of Fong's 1,365 survey respondants from the city of Dalien in 1999 had studied abroad (Fong 2011: 3). Fong shows that the desire to go abroad was shared by all students regardless of their socioeconomic background, and that parents would go a long way to save for a child's study abroad. Rural students in my own study certainly also shared the wish to study abroad, but the vast majority of them regarded it as completely unrealistic, not only because of financial constraints but because their family lacked the knowledge of how to operate in the complex global system of educational migration. Less than 5 percent of Chinese students abroad are funded by the government and the norm is to rely on family finances. ${ }^{\text {xix }}$ Therefore, in spite of the high number of Chinese students in foreing universities, it is important to keep in mind that is still only a very small minority of Chinese children who have this opportunity. Figures are uncertain and often difficult to compare across countries, but according to Unesco Institute for Statistics only 0.6 percent of the entire tertiary age group in China 2012 left to study abroad (referred in (A. S. Hansen and Thøgersen 2015, 4).

Since 2013, the government has reported that about 70-80 percent of students return to China to find work, a higher proportion of outbound students than seen in previous years (ICEF Monitor 2016). We lack data showing if these returnees then succeed in actually achieving what Fong in the quotation above reported to be their aim.

Regardless, the widespread urge to study abroad suggests, at least, that there is a strong belief in the potential of "foreign" (guowai) education, meaning, in effect, studies in the so-called "developed countries". This perceived potential benefit of studying abroad, however, is not merely grounded in rational choice focusing on the opportunity for upward mobility. It is perceived as much as an option for gaining life changing experiences and for broadening of the individual's horizons (Fong 2011; A. S. Hansen 2015; A. S. Hansen and Thøgersen 2015).

Since an ever growing number of Chinese middle class and elite family children now choose to study abroad, in democractic states' education systems mainly, and then return home to work, one might expect to find new forms of pressure for change of 
Chinese education. This is an understudied topic, but recent fieldwork suggests that Chinese students abroad may in fact be more engaged in policies of education at home than commonly assumed. Thøgersen's (2015) indepth study of BA-students in a program for pre-school education has shown how students in a double degree program strenghtened their views on the need for reforming Chinese education after having spent a year in a Danish college as part of a double degree. Like students in the other fieldwork based studies discussed above, these BA students had been highly critical to the Chinese schools' focus on exams and discipline already at the level of high school. They had, like so many students and teachers in China, cultivated a rather fixed idealized view of Western education as the Chinese education's ultimate "Other", as a more free, open, creative and less demanding form of schooling.

However, Thøgersen shows how these students, during their one-year stay Denmark, increasingly give substance to their views on how Chinese education should be changed. They do not ask for politial systemic change and by no means do they become political dissidents. But they nevertheless develop and express a strong - and clearly political - wish that Chinese education to a larger extent incorporate the values of what they called "freedom", "individual rights", "equality" and "creativity". They wanted freedom for children to play, respect for students' right to privacy, equality between teachers, students, and parents, and they want an education system that encourages sponateity and thereby stimulate creativity.

These students' criticism and suggestions for changes are in fact very much in line with the official discourse of the need to make China a more innovative (chuangxin) society through reforms of the education system. More research is needed to see how and to which extent returning students manage to put into pratice some of these views and ideas when returning to the labor market in China. In their own - quite realistic views, they would maybe be able to make miniscule changes in daily practices (Thøgersen 2015, 121). In view of the processes of individualization in China that have led to students' strong feelings of personal responsibility for failure, but also to hightened expectations of personal choice and freedoms, the party-state might very well see the need for continuing, even strengthening, its attempts to secure young people's political loyalty and accept of authority through the schools' disciplining practices. Is it indeed doubtful if returning students with liberal ideas of socialization in education will be able to make any substantial changes to the education system.

The alternative educational path leading to studies abroad has been widened. It is now chosen by those who can afford it and idealized by those who can't. It will probably result in the introduction of different teaching methods and values in schools, especially in urban areas where returnees find jobs. This, however, will be on a small scale, and the real impact of choosing this alternative path is most more likely on students individual life experiences and their careerwise futures.

\section{The Way Ahead: Concluding Reflextions}

In the past 20 years the government has done much to make compulsory education affordable and accessible also to children in poorer inland and border regions. Scholarship programs have made it easier for students from poor families to accept offers of tertiary education in expensive cities if they pass through the entrance exam, 
and in the 2000s more attention than ever is being paid towards the education also of rural children who have migrated to the cities with their parents. At the same time, social discrepencies are deepening. Urban residents get into esteemed urban colleges with lower grades than rural residents, and ethnic minorities are increasingly depraved of the opportunity to study in their own language. Vocational eduction is highly praised by government and industry but is, for good reasons probably, regarded as second-class and a last option only by the general public. It remains to be seen if any political leaders or university teachers will support their own children going to vocational school if alternatives are available. And alternatives are available now. For those who can afford it and understand how to operate in a bureaucratic system the global education market has opened up a wealth of opportunities, hierarchically ordered from prestigeous US Ivy league universities to minor colleges around the Western world. On the other hand, socially disadvantaged students from poorer rural areas, from urban migrant families, or from vocational schools are hardly able to join the go-abroad-craze because of the lack of state support for it. Basic education for all is strenghtened, while social hierarchies created by the educational system are likely to continue deepening. 


\section{List of References}

Bailey, Paul John. 2007. Gender and Education in China: Gender Discourses and Women's Schooling in the Early Twentieth Century. Taylor \& Francis.

Bailey, Professor Paul John. 1993. Reform the People: Changing Attitudes Towards Popular Education in Early Twentieth-Century China. Edinburgh: Edinburgh University Press.

Bakken, Børge. 2000. The Exemplary Society: Human Improvement, Social Control and the Dangers of Modernity in China. Oxford: Oxford University Press.

Bass, Catriona. 1998. Education in Tibet : Policy and Practice Since 1950. London, New York: Zed Press.

Bastid, Marianne. 1988. Educational Reform in Early Twentieth-Century China. Translated by Paul Bailey. Ann Arbor: Center for Chinese Studies, The Universi.

Dikotter, Frank. 2010. Mao's Great Famine: The History of China's Most Devastating Catastrophe, 1958-62. Bloomsbury Publishing PLC.

Dikötter, Frank. 2016. The Cultural Revolution: A People's History, 1962-1976. Bloomsbury Press.

Elman, Benjamin A., and Alexander Woodside, eds. 1994. Education and Society in Late Imperial China, 1600-1900. Berkeley: University of California Press.

Fong, Vanessa L. 2004. Only Hope: Coming of Age under China's One-Child Policy. Stanford: Stanford University Press. 2011. Paradise Redefined: Transnational Chinese Students and the Quest for Flexible Citizenship in the Developed World. Stanford: Stanford University Press.

Hannum, Emily, Peggy Kong, and Yuping Zhang. 2009. "Family Sources of Educational Gender Inequality in Rural China: A Critical Assessment." International Journal of Educational Development 29 (5): 474-86. doi:10.1016/j.ijedudev.2009.04.007.

Hannum, Emily, Meiyan Wang, and Jennifer Adams. 2010. "Urban-Rural Disparities in Access to Primary and Secondary Education under Market Reform." In One Country, Two Societies? Rural-Urban Inequality in Contemporary China, edited by Martin King Whyte. Boston: Harvard University Press.

Hannum, Emily, Yuping Zhang, and Meiyan Wang. 2013. "Why Are Returns to Education Higher for Women than for Men in Urban China?" The China Quarterly 215 (September): 616-640. doi:10.1017/S0305741013000696.

Hansen, Anders Sybrandt. 2015. "The Temporal Experience of Chinese Students Abroad and the Present Human Condition." Journal of Current Chinese Affairs 44 (3): 49-77.

Hansen, Anders Sybrandt, and Stig Thøgersen. 2015. "The Anthropology of Chinese Transnational Educational Migration." Journal of Current Chinese Affairs 44 (3): 3-14.

Hansen, Mette Halskov. 1999. Lessons in Being Chinese: Minority Education and Ethnic Identity in Southwest China. Seattle, Wash.: University of Washington Press. . 2001. "Ethnic Minority Girls on Chinese School Benches: Gender Perspectives on Minority Education." In Education, Culture and Identity in Twentieth Century China, edited by Lu Yongling, Ruth Hayhoe, and Glen Petersen, 403-29. Ann Arbor: University of Michigan Press. 
. 2012. "Recent Trends in Chinese Rural Education: The Disturbing RuralUrban Disparities and the Measures to Meet Them." In Towards a New Development Paradigm in Twenty-First Century China: Economy, Society and Politics, edited by Eric Florence and Pierre Defraigne, 165-79. London: Routledge.

. 2013. "Learning Individualism: Hesse, Confucius, and Pep-Rallies in a Chinese Rural High School.” The China Quarterly 213: 60-77.

. 2015. Educating the Chinese Individual: Life in a Rural High School. Seattle: University of Washington Press.

Hansen, Mette Halskov, and Rune Svarverud. 2010. iChina: The Rise of the Individual in Modern Chinese Society. Copenhagen: NIAS Press.

Hansen, Mette Halskov, and T.E. Woronov. 2013. "Demanding and Resisting Vocational Education: A Comparative Study of Schools in Rural and Urban China." Comparative Education 49 (2): 242-59.

ICEF Monitor. 2016. "A Record Number of Chinese Students Abroad in 2015 but Growth Is Slowing." ICEF Monitor - Market Intelligence for International Student Recruitment. April 6. http://monitor.icef.com/2016/04/a-recordnumber-of-chinese-students-abroad-in-2015-but-growth-is-slowing/.

Jones, Alisa. 2012. History and Citizenship Education in Post-Mao China: Politics, Policy, Praxis. 1sted. Routledge.

Kipnis, Andrew. 2011. Governing Educational Desire: Culture, Politics, and Schooling in China. Chicago: University of Chicago Press.

Kleinman, Arthur, Yan Yunxiang, Jun Jing, Lee Sing, and Everett Zhang, eds. 2011. Deep China: The Moral Life of the Person. University of California Press.

Kong, Peggy A. 2015. Parenting, Education, and Social Mobility in Rural China: Cultivating Dragons and Phoenixes. London; New York: Routledge.

Lee, Thomas. 2000. Education in Traditional China: A History. Leiden ;;Boston: Brill.

Leibold, James, and Chen Yangbin, eds. 2014. Minority Education in China: Balancing Unity and Diversity in an Era of Critical Pluralism. Hong Kong University Press. http://www.jstor.org/stable/j.ctt5vj8vd.

Liu, Mingxing, Rachel Murphy, Ran Tao, and Xuehui An. 2009. "Education Management and Performance after Rural Education Finance Reform: Evidence from Western China." International Journal of Educational Development 29 (5): 463-73. doi:10.1016/j.ijedudev.2009.04.013.

Murphy, Rachel. 2004. “Turning Peasants into Modern Chinese Citizens: 'Population Quality' Discourse, Demographic Transition and Primary Education.” The China Quarterly, no. 177: 1-20.

. 2014. "Study and School in the Lives of Children in Migrant Families: A View from Rural Jiangxi, China." Development and Change 45 (1): 29-51. doi:10.1111/dech.12073.

Pepper, Suzanne. 1996. Radicalism and Education Reform in 20th-Century China: The Search for an Ideal Development Model. Cambridge; New York: Cambridge University Press.

Pieke, Frank N. 2009. The Good Communist: Elite Training and State Building in Today's China. 1sted. Cambridge: Cambridge University Press.

Pinar, William F., ed. 2014. Curriculum Studies in China - Intellectual Histories. Palgrave Macmillan.

Postiglione, Gerard, ed. 1999. China's National Minority Education: Culture, Schooling, and Development. New York: Falmer Press. 
Rawski, Evelyn. 1979. Education and Popular Literacy in Ch'ing China. Ann Arbor: University of Michigan Press.

Schoenhals, Martin. 2001. "'Education and Ethnicity among the Liangshan Yi." In Perspectives on the Yi of Southwest China, edited by Stevan Harrell. Berkeley: Univ. of California Press.

Schulte, Barbara. 2012. "Unwelcome Stranger to the System: Vocational Education in Republican China." Comparative Education 49 (2): 1-16.

Thøgersen, Stig. 1990. Secondary Education in China After Mao: Reform and Social Conflict. Aarhus: Aarhus University Press. . 2002. A County of Culture: Twentieth-Century China Seen From the Village Schools of Zouping, Shandong. Ann Arbor: University of Michigan Press. . 2015. "I Will Change Things in My Own Small Way': Chinese Overseas Students, 'Western' Values, and Institutional Reform." Journal of Current Chinese Affairs 44 (3): 103-24.

Unger, Jonathan. 1982. Education under Mao: Class and Competition in Canton Schools, 1960-1980. New York: Columbia University Press.

Vickers, Edward. 2009a. "The Opportunity of China? Education, Patriotic Values and the Chinese State." In Education as a Political Tool in Asia, edited by Marie Lall and Edward Vickers. London and New York: Routledge. . 2009b. "Selling 'Socialism with Chinese Characteristics' 'Thought and Politics' and the Legitimisation of China's Developmental Strategy." International Journal of Educational Development 29 (5): 523-31.

Woronov, T. E. 2012. "Doing Time: Mimetic Labor and Human Capital Accumulation in Chinese Vocational Schools." South Atlantic Quarterly 111 (4): 701-19.

Woronov, Terry. 2015. Class Work: Vocational Schools and China's Urban Youth. Stanford: Stanford University Press.

Yan, Yunxiang. 2009. The Individualization of Chinese Society. London: Athlone Press.

. 2010. "The Chinese Path to Individualization." The British Journal of Sociology 61 (3): 489-512.

\section{Endnotes}

\footnotetext{
${ }^{\mathrm{i}}$ For indepth studies of early 20th century changing views on education and resulting reforms see for instance (P. P. J. Bailey 1993; Bastid 1988). See (Pinar 2014)for an edited volume with articles summarizing curricula developments in modern China. ii (Schulte 2012).

${ }^{\text {iii }}$ For more studies of early 20th century changing views on education and resulting reforms see for instance (P. P. J. Bailey 1993; Bastid 1988).

${ }^{\text {iv }}$ Only in 1907 was female eduation officially sanctioned by the Qing Dynasty and education for girls continued to develop very slowly during the early years of the Republic (P. J. Bailey 2007). For studies on gender inequality in contemporary education see also, for instance, (Hannum, Kong, and Zhang 2009; Hannum, Wang, and Adams 2010; Hannum, Zhang, and Wang 2013; M. H. Hansen 2001).

${ }^{\mathrm{v}}$ For studies of ethnic minority education see for instance (Bass 1998; M. H. Hansen 1999; Leibold and Yangbin 2014; Postiglione 1999; Schoenhals 2001)
} 


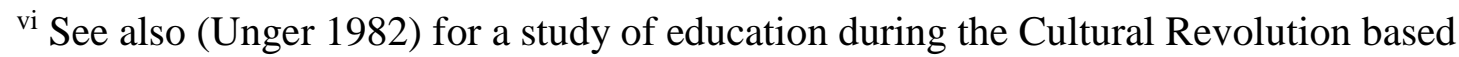
on interviews in Hong Kong with people who had fled China.

${ }^{\text {vii }}$ Figures are from the Sina.com education website that provides an overview of official college entrance exam statistics since 1977:

http://edu.sina.com.cn/gaokao/2015-06-18/1435473862.shtml (accessed 20 May 2016).

viii (Fong 2004)

ix (Kipnis 2011; Kong 2015; Murphy 2004)

${ }^{x}$ For instance (Hannum, Wang, and Adams 2010; M. H. Hansen 2012; Liu et al. 2009; Murphy 2004; Murphy 2014)

xi (M. H. Hansen 1999) and (M. H. Hansen 2015).

xii See also, for instance, (Vickers 2009b) on the use of models when teaching "thought and politics" and (M. H. Hansen 2015, 88-94) on students' perception of Lei Feng as a modern model.

${ }^{x i i i}$ A lot has been written about the discourse of Quality (suzhi) in China and Chinese eduation. See especially (Kipnis 2011) for an analysis of its meaning and importance in the practice of Chinese education.

${ }^{x i v}$ For instance (M. H. Hansen and Woronov 2013; Kipnis 2011; Schulte 2012;

Thøgersen 1990, 83-84; T. E. Woronov 2012)

${ }^{\mathrm{xv}}$ see also (M. H. Hansen and Woronov 2013) for a comparison between vocational classes in urban and rural areas.

${ }^{x v i}$ For examples of analasys of text books see for instance (M. H. Hansen 2015,

Chapter 2; Jones 2012; Vickers 2009b).

xvii See (Pieke 2009).

xviii On the "rise of the individual" and processes of individualization in China see, for instance, (M. H. Hansen and Svarverud 2010; Kleinman et al. 2011; Yan 2009; Yan 2010)

${ }^{x i x}$ See for instance article on the official Chinese website china.org.cn http://www.china.org.cn/china/2015-06/11/content 35792851.htm (accessed 8 June 2016). 